\title{
Toxic effect of heavy metals in livestock health
}

\author{
Mukesh K. Raikwar, Puneet Kumar, Manoj Singh and Anand Singh \\ Indian Veterinary Research Institute \\ Izatnagar - 243 122, Bareilly (U.P.)
}

\section{I ntroduction}

Heavy metals constitute a very heterogeneous group of elements widely varied in their chemical properties and biological functions. The term "heavy metals" defined as commonly held for those metals, which have specific weights more than $5 \mathrm{~g} \mathrm{~cm}-3$ (Holleman andWiverd, 1985). Heavy metals are kept under environmental pollutant category due to their toxic effects in plants, human and food. Some of the heavy metalsi.e. arsenic (As), Cadmium (Cd), Lead $(\mathrm{Pb})$, Mercury $(\mathrm{Hg})$ are cumulative poison. These heavy metals are persistence, accumulate and not metabolized in other intermediate compounds and do not easily breakdown in environment. These metals are accumulating in food chain through uptake at primary producer level and than through consumption at consumer level. Metals are entering the human body either through inhalation or injection.

Heavy metals such as $\mathrm{Cd}, \mathrm{Ni}, \mathrm{As}, \mathrm{Pb}$ pose a number of hazards to humans. These metals are also potent carcinogenic and mutagenic. Copper and zinc serve either as cofactor as a activator biochemical reactions \& enzymatic for information of enzyme/ substrate metal complex (Mildvan, 1970). The high concentration intake of cadmium cause itai itai disease and mercury intake lead to minamita disease and other heavy metals cause poisoning due to drinking water contamination.

Heavy metals have largest availability in soil and aquatic ecosystem and to relatively smaller proportion in atmosphere at particular vapors. Metal toxicity to plants varies with plants species, specific metals, concentration, chemical form, soil composition, $\mathrm{pH}$ and many metals considered to be essential for plants growth.

\section{Source of contamination}

Heavy metals pollution can originate from natural and anthropogenic sources. Activities such as mining \& smelting operation and agriculture, have contaminated extensive area of world such as Japan, Indonesia, and China mostly such as $\mathrm{Cd}, \mathrm{Cu}$ and $\mathrm{Zn}$ (Herawati et al., 2000) $\mathrm{Cu}$ and $\mathrm{Pb}$ in north Greece (Zantopoulos et al., 1999), Cu, Pb, Cu, Ni, Zn, and Cd in Austrilia (Smith et al., 1996). In animal body, metals are enter through animals feeds, green fodder, drinking water and pharmaceutical medicines etc. Other sources are accidental access to limed field, mineral supplements with high content of trace metal and licking of painted surfaced containing metallic pigments.

\section{Classification of Heavy metal}

Heavy metals can be classified into four major groups on their health importance.

Essential: $\mathrm{Cu}, \mathrm{Zn}, \mathrm{CO}, \mathrm{Cr}, \mathrm{Mn}$ and $\mathrm{Fe}$. These metal also called micronutrients (Reeves and Baker, 2000) and are toxic when taken in excess of requirements (Monni et al., 2000; Blaylock and Huang, 2000). The toxic limit and recommended or safe intake of heavy metal for human health is given in Table - 1 (Oliver, 1997)

Non essential : $\mathrm{Ba}, \mathrm{Al}, \mathrm{Li}$ and $\mathrm{Zr}$

Less toxic : Sn and Al

Highly toxic : $\mathrm{Hg}, \mathrm{Cd}$ and $\mathrm{Cd}$.

Heavy metals are also called trace element due to their presence in trace $(10 \mathrm{mg} \mathrm{Kg}-1)$ or in ultratrace $(1 \mu \mathrm{g} \mathrm{kg}-1)$ quantities in the environmental matrices.

Table-1: Toxic Limit and recommended / safe intake of heavy metal

\begin{tabular}{|l|l|l|}
\hline Heavy Metal & Toxic Limit & Recommended intake / Safe intake \\
\hline Arsenic & $3 \mathrm{mg} /$ day for $2-3$ weeks & $15-25 \mu \mathrm{g} /$ day (adults) \\
Cadmium & $200 \mu \mathrm{g} / \mathrm{kg}$ of fresh weight & $15-50 \mu \mathrm{g} /$ day adults $2-25 \mu \mathrm{g} /$ day children, \\
Lead & $\geq 500 \mu \mathrm{g} / \mathrm{L}$ (Blood) & $20-280 \mu \mathrm{g} /$ day adults $10-275 \mu \mathrm{g} /$ day children \\
Zinc & $150 \mu \mathrm{g} / \mathrm{day}$ & $15 \mu \mathrm{g} / \mathrm{day}$ \\
\hline
\end{tabular}


Toxic effect of heavy metals in livestock health

Cadmium (Cd): Pure cadmium is a soft, silver-white metal. The physical property of cadmium is atomic number 48, atomic weight 112.411 , electro-negativity 1.5 , crystal ionic radius (Principal valence state) 0.97 , ionisation potential 8.993 , oxidation state +2 , Electron configuration $\mathrm{Kr}$ 4d1 $5 \mathrm{~S} 2$ Density $8.64 \mathrm{~g} / \mathrm{cm} 3$, Melting point $320.9^{\circ} \mathrm{C}$ and Boiling point $765^{\circ} \mathrm{C}$ at $100 \mathrm{kPa}$. It is usually found as a mineral combined with other elements such as oxygen (cadmium oxide), chlorine (cadmium chloride), or sulphur (cadmium sulphate, cadmium sulphide).

Cadmium is a toxic to virtually every system in the animal body. It is almost absent in the human body at birth, however accumulates with age. An average men accumulates as about $30 \mathrm{mg}$ cadmium in his body by the age of 50 years. Refined foods, water foods, water pipes, coffee, tea, coal burning and cigrates are all the most important source of $\mathrm{Cd}$. Daily dietary intake of $\mathrm{Cd}$ ranges from $40-50 \mu \mathrm{g} /$ day (WHO, 1987). Cadmium accumulated with in the kidney and liver over long time (McLaughlin et al., 1999). It is interact with numbers of minerals mainly $\mathrm{Zn}, \mathrm{Fe}, \mathrm{Cu}$ and Se due to chemical similarities and competition for binding stage. It is also reported that $\mathrm{Cd}$ can affected $\mathrm{Ca}, \mathrm{P}$ and bone metabolism in both industrial and people exposed to $\mathrm{Cd}$ in general environment (Jarup et al., 1998).

Lead $(\mathbf{P b})$ : Lead is a bluish or silvery grey soft metal with atomic number 82; atomic weight 207.19; specific gravity 11.34 , melting point $327.5^{\circ} \mathrm{C}$ and boiling point $17400 \mathrm{C}$. It is the most common industrial metal that has become widespread in air, water, soil and food. Lead is slightly soluble in water and is transported mainly through the atmosphere. It behaves like calcium in body and accumulates in bone, liver, kidney and other tissues.

The problem of lead poisoning in animals has widely been recognized which needs a special attention for the environmentalist and healthpersonnel. It is a cumulative tissue poison and gets stored in different parts of the body especially in bones, liver, kidney and brain. Besides, direct ingestion of lead leading to increased blood lead levels, accumulated lead in the body also acts as a significant source of blood lead burden (Swarup et al., 2005). Accumulated lead is mobilized from the storage sites with decreasing blood lead level or following treatment with chelator, thus enhancing the chelator blood lead level without the animal being exposed to lead in the immediate past. Chelation treatment sometimes leads to fatal outcome due to immediate surge of lead from the deposited site to blood causing severe damages to kidney and brain. Lead produces mainly acute or chronic poisoning. In acute lead poisoning case fatality in lead poisoning may go up to as high as $100 \%$. In acute lead toxicity in cattle, there is sudden onset of signs and the animal at pasture may succumb within 24 hours.

Arsenic (As): The organoarsenicals in food are one of the most poisoning in livestock now a days because of the displacement of arsenic form almost all phases of farming activities. The common of source of arsenic is in fluid used for dipping and spraying of animal to control ecto-parasites. Clinical signs of arsenic toxicity in cattle vary form gastrointestinal to nervous signs. Arsenic were killer including sodium or sodium arsenate, Arsenic pentaoxide and monosodium or disodium acid. It toxicity produces goiter in rats, thyroid antagonism in man and inhibited the growth of rumen bacteria in pure culture as well as reduces the fermentative activity. Chronic arsenic toxicity is mostly manifested in weight loss, capricious appetite, conjunctively and mucosal erythematic lesion including mouth ulceration and reduce milk yield. Acute toxic effects include abdominal cramping, hyperesthesia in extremities, abdominal patellar reflexes and abdominal electrocardiogram (Franzblau and Lilis, 1989). Such effects generally occur at the levels of exposure equal to $50 \mu \mathrm{g} / \mathrm{kg}$ weight/day. However, chronic poisoning of As includes anemia, liver and kidney damage, hyper pigmentation and keratosis i.e. skin damage (Wu et al., 1989; ATSDR, 2000).

It is reported that As toxicity produced goiter in rats, thyroid in man. Arsenic inhibited the growth of rumen bacteria in pure culture as well reduced the fermentative activity.

Mercury ( $\mathbf{H g}$ ): Mercury is considered a highly toxic contaminant. The toxicity of mercury depends on its chemical form methyl mercury being the most hazardous metal and stable form of mercury that has been attributed to the suffering of most avian and mammalian predators at the top of contaminated tropics. Industrial wastes and sewage water form the chloroalkali industry are a major source of mercury pollution. The symptoms of toxicosis in most species of animals include in coordination of movement, visual aberration and decline in awareness. Fishes containing more than $0.4 \mathrm{ppm} \mathrm{Hg}$ are unfit human consumption, the critical urinary concentration of $\mathrm{Hg}$ has been suggested as 1 to $2 \mu \mathrm{g} / \mathrm{ml}$. Minimata disease is characterized by 
Toxic effect of heavy metals in livestock health

symptoms of fatigue, loss of memory and concentration, tremors' constriction of visual field, cortical blindness etc. (Jarup, 2003). The intake of mercury as suggested by $\mathrm{WHO}$ is $43 \mu \mathrm{g}$ (Krishnamurti, 1987). The animal consumed high mercury containing vegetation will be affected and will suffer from alopecia, neuropathy, visual and gastrointestinal tract disorder.

\section{References}

1. ATSDR (Agency for Toxic Substances and Disease Registry) (2000). Toxicological profile for arsenic U.S. Department of health and human service, Public Health Service, A-5

2. Blaylock, M.J. and J.W. Huang. (2000). Phytoextraction of metal. In: Phytoremediation of toxic metal: Using plants to clean. Up the environmental. (Ed: I. Raskin and B.D. Ensley). John Wiley \& Sons, Torento, Canada. pp. 53-70.

3. Franzblau, A. and Lilis, R. (1989): Archives of Environmental Health. 44: 385-390.

4. Herawati, N., Susuki, S., Hayashi, K., Rivai, I.F. and Koyama, H. (2000): Bulletin of Environmental Contamination and Toxicology. 64: 33-39.

5. Holleman, A.F. and Wiberg, E. (1985). Lehebuch du Anoranischen chemie. Water de Gruyter, Berlin, pp-868.

6. Jarup, L. (2003): British Medical Bulletin. 68: 167-182.

7. Jarup, L., Bergluud, M. and Elinder, C.G. (1998): Scandian Journal of Work Environmental Health. 24: 1-51.
8. Krishnamurti, C.R. (1987): The cycling of arsenic, cadmium, lead and mercury in India. In: Lead, mercury, cadmium and arsenic in the environmental. (Eds: C. Hutchinson and K.M. Meema).SCOPE31, John Wiley and Sons, Chichester, pp 315-333.

9. McLaughlin, M.J., Parker, D.R. and Clarke, J.M. (1999): Field Crop Research. 60: 143-163.

10. Mildvan, A.S. (1970): Metals in enzymes catalysis. In: The enzymes, Vol. II (Ed: D.D. Boyer). Academic Press, London. pp 445-536.

11. Monni, S., Salemaa, M. and Miller N. (2000): Environmental Pollution. 109: 221-229.

12. Oliver, M.A. (1997): European Journal of Soil Science. 48: 573-592.

13. Reeves, R.D. and Baker A.J.M. (2000): Metal accumulation plants. In: Phytoremediation of toxic metals: Using plant to clean up the environment. (Ed: I. Raskin and B.D. Ensely). John Wiley and Sons, Inc. Torento, Canada. pp - 193-229.

14. Smith, C.J., Hopmans, P. and Cook, F.J. (1996): Environmental Pollution. 94: 317-323.

15. Swarup D, Patra RC, Naresh R, Kumar P, Shekhar P.<http://www.ncbi.nlm.nih.gov/entrez/(2005). Science of the Total Environment. 15(1-3): 67-71

16. WHO (1987): Air quality guidelines for Europe. WHO Regional Publications, European Series No. 23. World Health Organization officer for Europe, Copenhagen.

17. Wu, M.M., Kuo, T.L., Huang Y.H. and Chen C.J. (1989): American Journal of Epidermology. 130: 1123-1132.

\section{Operation Flood made I ndia one of the largest producer of milk in the world}

Milk production was stagnant in India in the 1950s and 1960s. The Government wanted to increase milk production and improve its distribution in an attempt to alleviate poverty and mal-nutrition. For this, India received aid from the European countries through the World Food Programme.

The Government expended the money in an innovative and intelligent manner. Instead of distributing the gifts of milk and dairy products free, milk powder was used to manufacture liquid milk and sell it. The funds thus generated were invested in a project termed "Operation Flood". A National Milk grid was created, which linked milk producers throughout India. Milk production was encouraged through co-operatives of the milk producers. Dairy farmers benefited because they were not affected by seasonal and regional price fluctuations. The project was a huge success - it made India one of the largest producers of milk in the world. This was hailed as the "White Revolution".

The project was implemented in three phases. Phase one was from1970 to 1980.It covered eight of India's major cities. Phase two was from 1980 to 1985. Milk sheds increased from 18 to 136. Urban markets expanded. There were 290 outlets. A self-sustaining system had been set up by the end of phase two. In phase three (between 1985 to 1996) there has been a further increase in milk cooperatives: 30,000 co-operatives have been added. The facilities have been expanded to provide veterinary care. Efforts are made to see that the cattle feed is of good quality. Research has been undertaken in the fields of animal breeding, animal health and nutrition. 